\title{
Descrição de seis espécies de Chinavia (Hemiptera, Pentatomidae, Pentatominae) da América do Sul ${ }^{1}$
}

\author{
Cristiano F. Schwertner ${ }^{2,3}$ \& Jocélia Grazia ${ }^{2,4}$
}

1. Contribuição $\mathrm{N}^{\mathrm{o}} 485$ do Departmento de Zoologia, Instituto de Biociências, Universidade Federal do Rio Grande do Sul.

2. Departamento de Zoologia, Instituto de Biociências, Universidade Federal do Rio Grande do Sul. Av. Bento Gonçalves, 9500, Bloco IV, Prédio 43435, 91501-970 Porto Alegre, RS, Brasil.

3. Programa de Pós-Graduação em Biologia Animal, Universidade Federal do Rio Grande do Sul. Bolsista CNPq. (acrosternum@yahoo.com.br)

4. Bolsista CNPq. (jocelia@ufrgs.br)

\begin{abstract}
Description of six new species of Chinavia (Hemiptera, Pentatomidae, Pentatominae) from South America. Six new species of Chinavia Orian, 1965 are described: Chinavia vanduzeei sp. nov., from Peru (Madre Dios) and Brazil (Pará); Chinavia schuhi sp. nov., from Peru (Loreto), Colombia (Bolívar) and Brazil (Amazonas); Chinavia sebastiaoi sp. nov., from Brazil (Mato Grosso do Sul), Bolivia (La Paz and Santa Cruz) and Paraguai (Carumbé); Chinavia cearensis sp. nov., Chinavia tuiucauna sp. nov., and Chinavia rufitibia sp. nov., from Brazil (Ceará, Bahia and Paraná, respectively). Diagnoses to each species are given.
\end{abstract}

KEYWORDS. Taxonomy, morphology of genitalia, Neotropical, host-plants, Nezarini.

RESUMO. Seis novas espécies de Chinavia Orian, 1965 são descritas: Chinavia vanduzeei sp. nov., do Peru (Madre Dios) e Brasil (Pará); Chinavia schuhi sp. nov., do Peru (Loreto), Colombia (Bolívar) e Brazil (Amazonas); Chinavia sebastiaoi sp. nov., do Brazil (Mato Grosso do Sul), Bolivia (La Paz e Santa Cruz) e Paraguai (Carumbé); Chinavia cearensis sp. nov., Chinavia tuiucauna e Chinavia rufitibia sp. nov., do Brasil (Ceará, Bahia e Paraná, respectivamente). São fornecidas características diagnósticas de cada espécie.

PALAVRAS-CHAVE. Taxonomia, morfologia de genitália, Neotropical, plantas-hospedeiras, Nezarini.

O gênero Chinavia foi proposto por ORIAN (1965) para nove espécies afrotropicais transferidas de Acrosternum Fieber, 1860. Rolston (1983) tratou Chinavia como subgênero de Acrosternum, incluindo naquele táxon todas as espécies americanas de Acrosternum. No presente trabalho, baseados em evidências morfológicas e concordando com as propostas de Day (1965), Roche (1977) e Ahmad (1996), consideramos Chinavia como gênero. Na classificação proposta por RiDER (2005), este táxon foi incluído na tribo Nezarini.

Atualmente Chinavia contém 73 espécies descritas, distribuídas nas Regiões Afrotropical, Neártica e Neotropical. As espécies são de tamanho médio a grande, coloração predominantemente verde, bastante comuns e consideradas, em geral, polífagas (RoLSTON, 1983; PANIZZI et al., 2000; SCHWERTNER et al., 2002). Muitas espécies têm registro em plantas cultivadas, algumas citadas como pragas (PANizZI et al., 2000). Ao analisar material objetivando a revisão do gênero Chinavia, verificamos seis espécies ainda desconhecidas, que são aqui descritas.

\section{MATERIAL E MÉTODOS}

Exemplares estudados pertencem às seguintes instituições (sigla e nome dos curadores entre parênteses): American Museum of Natural History, Nova York, EUA (AMNH, R. T. Schuh); California Academy of Sciences, São Francisco, EUA (CAS, N. Penny); Coleção particular David A. Rider, Fargo, EUA(DAR, D. A. Rider); Centro Nacional de Pesquisa em Soja, EMBRAPA, Londrina, Brasil (CNPS, A. R. Panizzi); Departamento de Zoologia, Universidade Federal do Paraná, Curitiba, Brasil (DZUP, L. Marinoni); Departamento de Zoologia, Universidade Federal do Rio Grande do Sul, Porto Alegre, Brasil (DZRS, J. Grazia); Fundação Instituto Oswaldo Cruz, Rio de Janeiro, Brasil (FIOC, S. Oliveira, in memorian); Museu de Ciências Naturais, Fundação Zoobotânica do Rio Grande do Sul, Porto Alegre, Brasil (MCNZ, A. Barcellos); Fundación e Instituto Miguel Lillo, Universidad Nacional de Tucumán, Tucumán, Argentina (IMLA, M. V. A. de Toledo); Instituto Nacional de Pesquisas da Amazônia, Manaus, Brasil (INPA, J. A. Rafael); Instituto Alexander von Humboldt, Santa Fé de Bogotá, Colômbia (IAVH, J. E. Castillo); Museum National d'Histoire Naturelle, Paris França (MNHN, D. Plüot-Sigwald); National Museum of Natural History, Washington D.C., EUA(NMNH, T. J. Henry); The Natural History Museum, Londres, Inglaterra (BMNH, M. Webb). Medidas são fornecidas em milímetros; o tamanho das espécies (pequeno, médio ou grande) foi definido comparando-se com o tamanho médio das espécies do gênero. Os símbolos utilizados nas proporções dos segmentos da antena e do rostro são os seguintes: "<" menor; ">" maior; " $\approx$ " subigual. Quando o número de espécimes permitiu, foi caracterizada a genitália interna de machos e fêmeas. A nomenclatura das peças genitais segue Dupuis (1970) e FrEY-DA-Silva \& GraZia (2001), com modificações. 
Nas ilustrações do phallus, a parte da conjuntiva interna à phallotheca foi omitida.

Na genitália do macho, as abas do folheto superior do bordo ventral do pigóforo correspondem a $1+1$ abas localizadas lateralmente ao segmento X; são estruturas exclusivas das espécies de Chinavia e bastante variáveis quanto à forma. Têm forma basicamente subtriangular, superfície mais ou menos côncava e grau de inclinação variável nas espécies. As margens que delimitam as abas têm dimensões e contorno variados: margem ânterolateral externa curva ou retilínea, geralmente emarginada e enegrecida, com dentes, carena ou projeção espiniforme; margem ântero-lateral interna em geral sinuosa, por vezes inconspícua, delimitando o recorte interno do bordo ventral; margem posterior côncava, retilínea ou sinuosa.

\section{RESULTADOS E DISCUSSÃO}

\section{Chinavia cearensis sp. nov.} (Figs. 1, 7-9, 42)

Diagnose. Espécie reconhecida pela coloração verde-esmeralda, com o bordo do pronoto, do terço apical do hemiélitro e todo conexivo de coloração creme. Juntamente com C. gravis (Walker, 1867), são as duas únicas espécies que apresentam este padrão de cor. Chinavia cearensis diferencia-se desta forma de $C$. gravis pelas margens das jugas vermelho-alaranjadas, coloração creme das margens do pronoto, escutelo e hemiélitro menos conspícua, antenas e pernas não-manchadas de negro e membranas do hemiélitro transparentes.

Medidas. Comprimento médio s/l: 13,96/15,06; largura abdominal: 7,99/8,67. Demais parâmetros morfométricos, Tab. I.

Coloração. Face dorsal do corpo predominantemente verde-esmeralda. De coloração amarelo-creme: estreita faixa junto às margens ânterolaterais do pronoto, margens laterais do escutelo, margem do terço basal do cório, conexivo e margens dos urosternitos (Fig. 1). Externamente à faixa de coloração amarelo creme das jugas, uma faixa difusa vermelhoalaranjada. Pontuação, quando presente, concolor ao corpo. Mancha negra entre o olho e a base da antena ausente. Antenas predominantemente verdes, com terço apical do terceiro artículo negro, 3/4 apicais do quarto e do quinto artículos, ferrugíneos. Rostro verde a ferrugíneo. Cicatrizes do pronoto e ângulos basais do escutelo, imaculados. Esternos, coxas e trocanteres creme; no macho, ápice dos fêmures e base das tíbias vermelho-alaranjados. Membrana dos hemiélitros transparente, esverdeada. Conexivo creme, imaculado; ponto negro do ápice dos ângulos póstero-laterais dos urosternitos inconspícuos. Face ventral do abdome verde-clara a amarelo-creme. Espiráculos creme.

Cabeça. Jugas com disco plano; margens côncavas adiante dos olhos, convexas e convergentes anteriormente; ápice da cabeça semicircular. Proporção dos artículos antenais: $\mathrm{I}<\mathrm{II}<\mathrm{III}<\mathrm{IV} \approx \mathrm{V}$ (Tab. I). Rostro com ápice atingindo o espinho abdominal, não ultrapassando o meio do terceiro urosternito. Proporção dos segmentos do rostro: $\mathrm{I}<\mathrm{II} \approx \mathrm{III}>\mathrm{IV} ; \mathrm{I} \approx \mathrm{IV}$ (Tab. I).
Tórax. Pronoto com margens ântero-laterais subretilíneas, levemente emarginadas; ângulos umerais arredondados. Pontuações junto às margens ânterolaterais do pronoto, ápice do escutelo e dos hemiélitros mais rasas que no restante do corpo ou ausentes. Hemiélitros com ângulo costal do cório arredondado a subtruncado, ultrapassando o meio do conexivo VI; sutura da membrana retilínea. Peritrema ostiolar atingindo 3/4 da largura da metapleura.

Abdome. Convexo ventralmente. Conexivo pouco visível dorsalmente, com pontuações raras e mais rasas do que no restante do corpo. Espinho do terceiro urosternito inconspícuo, em forma de cunha, não atingindo as margens posteriores das metacoxas.

Genitália do macho. Pigóforo subquadrangular, ângulos póstero-laterais projetados (Fig. 7). Taça genital moderadamente escavada. Projeção mediana do bordo dorsal levemente convexa no ápice; terços laterais do bordo dorsal pouco projetados sobre a taça genital. Margens laterais dos ângulos póstero-laterais côncavas. Abas do bordo ventral moderadamente dobradas sobre a taça genital, ângulos anteriores projetados dorsalmente; margem lateral externa sinuosa, emarginada e dobrada sobre a taça genital na metade basal; limite da margem lateral interna pouco definido (Figs. 7, 9). Recorte mediano do bordo ventral em "U". Depressão do bordo ventral rasa, carena mediana conspícua (Fig. 8). Segmento X ogival, levemente convexo dorsalmente, escavação rasa; carena do segmento X semicircular (Figs. 7, 9).

Genitália da fêmea (Fig. 42). Sinuosidade do bordo posterior do segmento VII moderada sobre os ângulos basais dos laterotergitos 8. Gonocoxitos 8: superfície levemente convexa junto ao ângulos póstero-laterais, ângulos suturais emarginados, bordos suturais justapostos medianamente; bordos posteriores dos gonocoxitos 8 retilíneos, ângulos póstero-laterais desenvolvidos, arredondados. Gonapófises 8 pouco projetadas sobre os gonocoxitos 8 . Laterotergitos 9 com ápices rombos, margens internas levemente convexas. Bordo posterior dos gonocoxitos 9 levemente convexo; espinho do bordo posterior das gonapófises 9 desenvolvido, ultrapassando a metade dos gonocoxitos 9 , não encoberto pelas gonapófises 8 .

Material-tipo. Holótipo đ̊, BRASIL, Ceará: Serra do Baturité, Gounelle, coll. Noualhier 1898 (MNHN); Parátipo \&, com os mesmos dados do holótipo (DZRS).

Etimologia. Nome alusivo ao Estado do Brasil onde foram coletados os exemplares.

Distribuição. Brasil (Ceará).

Chinavia rufitibia sp. nov.

(Figs. 2, 10-12, 22-24, 34, 35, 43)

Diagnose. Espécie reconhecida pelo tamanho menor, coloração geral do corpo verde e as margens da cabeça, pronoto, hemiélitros e conexivo com estreita faixa amarela a amarelo-alaranjada; manchas da margem posterior do conexivo estendidas, pelo menos, até a metade da largura deste. Diferencia-se de C. impicticornis (Stål, 1872) e C. herbida (Stål, 1859) pelas tíbias avermelhadas e ângulos basais do escutelo imaculados. 
Medidas. Comprimento médio ł/ł: 10,05/12,16; largura abdominal: 6,07/7,02. Demais parâmetros morfométricos, Tab. I.

Coloração. Face dorsal verde-clara; margens das jugas e do pronoto, terço basal do cório, contorno da base dos olhos e dos ângulos ântero-laterais do pronoto com uma faixa amarelo-alaranjada; no conexivo, esta faixa é mais ampla, ocupando quase a totalidade da sua largura. Pontuação da face dorsal do corpo verde-escura, pontuação da cabeça concolor à superfície. Mancha negra entre o olho e a base da antena presente. Cicatrizes do pronoto e ângulos basais do escutelo imaculados. Segmentos antenais: primeiro, quarto e quinto verdes; segundo e terceiro vermelho-ferrugíneos. Rostro verde. Pernas predominantente verdes, com as tíbias vermelhoferrugíneas. Membrana dos hemiélitros transparente, com pequenas manchas enfuscadas junto à base e ao longo das veias (Fig. 2). Conexivo com mancha negra junto ao bordo posterior que se prolonga do ângulo póstero-lateral até a metade da largura do conexivo. Face ventral verdeclara, com uma faixa creme longitudinal mediana no tórax, às vezes também no abdome; pontuação da face ventral concolor; alguns exemplares com pontuaç̃es no tórax verde-escuras. Espiráculos verdes a castanho-claros, translúcidos.

Cabeça. Jugas com disco plano; margens laterais emarginadas, levemente côncavas adiante dos olhos, convexas posteriormente; ápice da cabeça rombo. Proporção dos artículos antenais: $\mathrm{I}<\mathrm{II}<\mathrm{III}<\mathrm{IV} \approx \mathrm{V}$ (Tab. I). Rostro com ápice atingindo as metacoxas. Proporção dos segmentos do rostro: $\mathrm{I}<\mathrm{II}>\mathrm{III}>\mathrm{IV}$; I $\approx \mathrm{IV}$ (Tab. I).

Tórax. Margens ântero-laterais do pronoto levemente convexas; ângulos umerais arredondados. Ângulos costais do cório arredondados, ultrapassando o bordo posterior do VI segmento do conexivo; sutura da membrana retilínea. Peritrema ostiolar estendendo-se além de 3/4 da largura da metapleura.

Abdome. Convexo ventralmente, com pontuação rosa, quase imperceptível. Conexivo pouco visível dorsalmente, pontuação mais rasa e menos densa do que na superfície dorsal do corpo. Espinho abdominal achatado lateralmente, atingindo a margem posterior das metacoxas.

Genitália do macho. Pigóforo subtriangular, ângulos

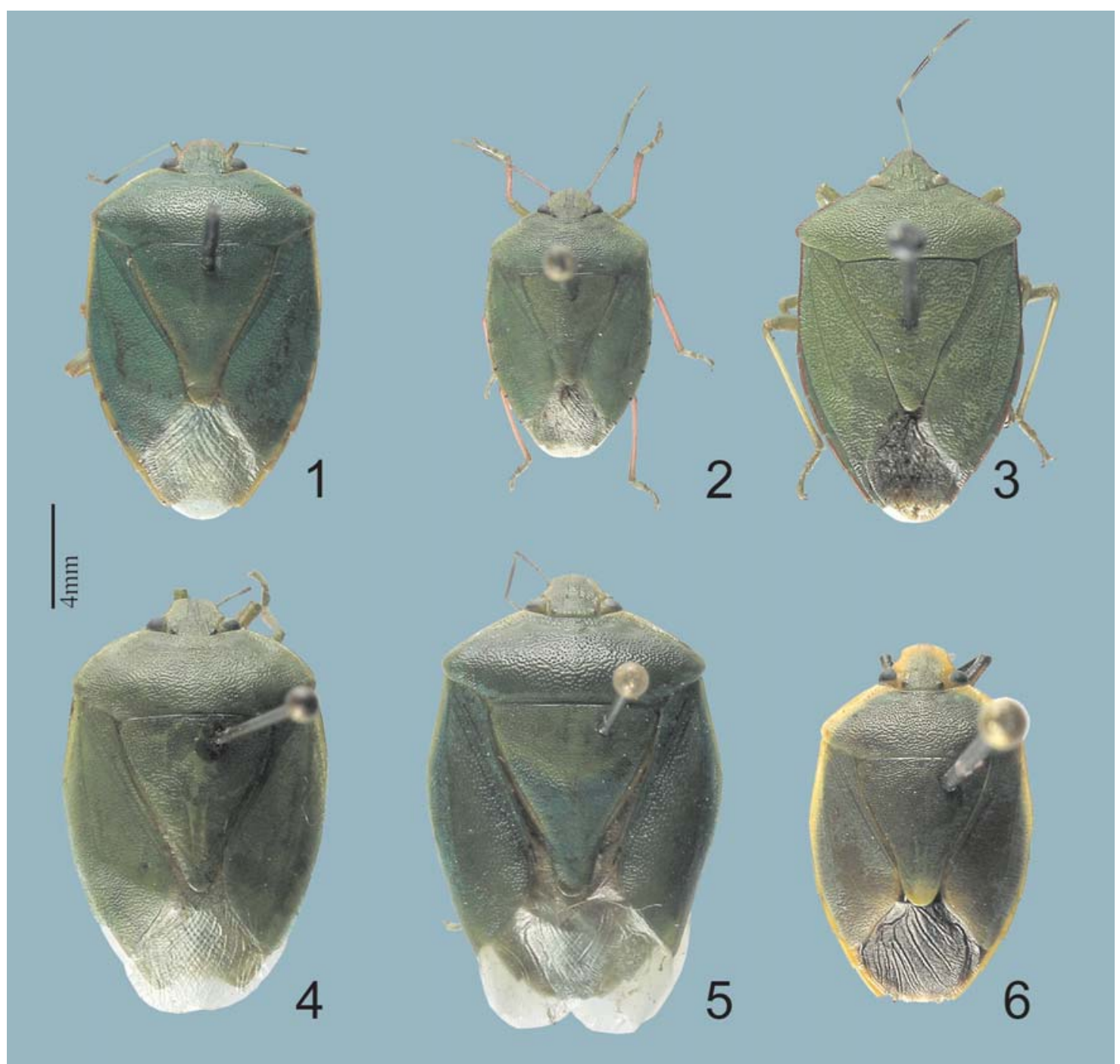

Figs. 1-6. Facies dorsal: 1, Chinavia cearensis sp. nov., holótipo ơ; 2, C. rufitibia sp. nov., holótipo ơ; 3, C. schuhi sp. nov., holótipo

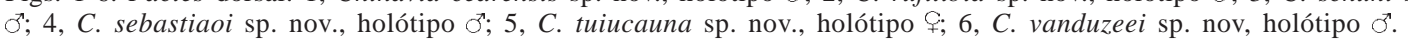


Tab. I. Parâmetros morfométricos de Chinavia spp. (AI-AV, comprimento dos artículos antenais I a V; CC, comprimento da cabeça; $\mathrm{CE}$, comprimento do escutelo; CP, comprimento do pronoto; DI, distância interocular; DP, desvio padrão; LC, largura da cabeça; LE, largura do escutelo junto aos ângulos basais; LP, largura do pronoto junto aos ângulos umerais; Máx, valor máximo; Méd, valor médio; Mín, valor mínimo; RI-RIV, comprimento dos artículos do rostro I a IV).

\begin{tabular}{|c|c|c|c|c|c|c|c|c|c|c|c|c|c|c|c|c|c|c|c|}
\hline & & & $\mathrm{CC}$ & LC & DI & $\mathrm{CA}$ & AI & AII & AIII & AIV & AV & RI & RII & RIII & RIV & $\mathrm{CP}$ & LP & $\mathrm{CE}$ & LE \\
\hline \multirow[t]{2}{*}{ C. cearensis } & 0 & & 2,40 & 2,88 & 1,68 & 1,20 & 0,64 & 1,12 & 1,52 & 2,16 & - & 1,04 & 1,76 & 1,52 & 1,20 & 2,56 & 7,36 & 5,20 & 4,72 \\
\hline & ॄ & & 2,48 & 3,04 & 1,84 & 1,28 & 0,64 & 1,12 & 1,52 & 2,08 & 2,24 & 1,12 & 1,84 & 1,52 & 1,20 & 2,64 & 7,84 & 5,52 & 4,96 \\
\hline \multirow[t]{5}{*}{ C. rufitibia } & $\vec{\sigma}$ & Méd & 1,89 & 2,49 & 1,46 & 0,92 & 0,46 & 0,86 & 1,03 & 1,35 & 1,55 & 0,73 & 1,22 & 0,94 & 0,75 & 1,99 & 5,85 & 3,97 & 3,80 \\
\hline & & DP & 0,06 & 0,05 & 0,04 & 0,05 & 0,00 & 0,03 & 0,08 & 0,05 & 0,05 & 0,03 & 0,05 & 0,10 & 0,04 & 0,09 & 0,14 & 0,10 & 0,09 \\
\hline & & Mín & 1,82 & 2,41 & 1,43 & 0,85 & 0,46 & 0,85 & 0,91 & 1,30 & 1,50 & 0,72 & 1,17 & 0,85 & 0,72 & 1,89 & 5,72 & 3,84 & 3,71 \\
\hline & & Máx & 1,95 & 2,54 & 1,50 & 0,98 & 0,46 & 0,91 & 1,11 & 1,43 & 1,63 & 0,78 & 1,30 & 1,04 & 0,78 & 2,15 & 6,11 & 4,10 & 3,90 \\
\hline & $q$ & & 2,02 & 2,67 & 1,50 & 0,98 & 0,52 & 0,98 & 1,17 & 1,56 & 1,63 & 0,91 & 1,50 & 1,04 & 0,91 & 2,28 & 6,63 & 4,75 & 4,10 \\
\hline \multirow[t]{8}{*}{ C. schuhi } & $\sigma$ & Méd & 2,28 & 2,80 & 1,65 & 1,15 & 0,54 & 1,24 & 1,54 & 1,97 & 1,99 & 1,28 & 2,12 & 1,86 & 1,32 & 2,38 & 7,48 & 5,09 & 4,77 \\
\hline & & DP & 0,06 & 0,06 & 0,08 & 0,04 & 0,04 & 0,06 & 0,04 & 0,08 & 0,10 & 0,04 & 0,10 & 0,10 & 0,08 & 0,16 & 0,32 & 0,30 & 0,29 \\
\hline & & Mín & 2,21 & 2,73 & 1,56 & 1,11 & 0,52 & 1,17 & 1,50 & 1,89 & 1,89 & 1,24 & 2,02 & 1,76 & 1,24 & 2,21 & 7,15 & 4,75 & 4,49 \\
\hline & & Máx & 2,34 & 2,86 & 1,69 & 1,17 & 0,59 & 1,30 & 1,56 & 2,02 & 2,08 & 1,30 & 2,21 & 1,95 & 1,37 & 2,54 & 7,80 & 5,27 & 5,07 \\
\hline & $q$ & Méd & 2,50 & 3,06 & 1,82 & 1,27 & 0,62 & 1,33 & 1,76 & 2,15 & 1,95 & 1,40 & 2,34 & 1,95 & 1,37 & 2,73 & 8,65 & 6,01 & 5,46 \\
\hline & & DP & 0,05 & 0,00 & 0,09 & 0,05 & & 0,05 & 0,00 & & & & 0,09 & & & 0,00 & & & 0,09 \\
\hline & & Mín & 2,47 & 3,06 & 1,76 & 1,24 & 0,59 & 1,30 & 1,76 & 2,08 & 1,95 & 1,30 & 2,28 & 1,89 & 1,30 & 2,73 & 8,58 & 5,98 & 5,40 \\
\hline & & Máx & 2,54 & 3,06 & 1,89 & 1,30 & 0,65 & 1,37 & 1,76 & 2,21 & 1,95 & 1,50 & 2,41 & 2,02 & 1,43 & 2,73 & 8,71 & 6,05 & 5,53 \\
\hline \multirow[t]{8}{*}{ C. sebastiaoi } & 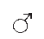 & Méd & 2,56 & 3,11 & 1,76 & 1,15 & 0,58 & 1,08 & 1,72 & 2,31 & 2,27 & 1,05 & 1,65 & 1,52 & 1,15 & 2,66 & 7,90 & 5,64 & 5,20 \\
\hline & & DP & 0,22 & 0,10 & 0,00 & 0,04 & 0,08 & 0,06 & 0,05 & 0,13 & 0,08 & 0,10 & 0,06 & 0,12 & 0,04 & 0,08 & 0,14 & 0,17 & - \\
\hline & & Mín & 2,40 & 3,04 & 1,75 & 1,12 & 0,52 & 1,04 & 1,68 & 2,21 & 2,21 & 0,97 & 1,60 & 1,43 & 1,12 & 2,60 & 7,80 & 5,52 & 5,20 \\
\hline & & Máx & 2,72 & 3,18 & 1,76 & 1,17 & 0,64 & 1,12 & 1,75 & 2,40 & 2,32 & 1,12 & 1,69 & 1,60 & 1,17 & 2,72 & 8 & 5,76 & 5,20 \\
\hline & $q$ & Méd & 2,67 & 3,44 & 4,13 & 1,24 & 0,62 & 1,15 & 1,84 & 2,35 & 2,34 & 1,15 & 1,94 & 1,53 & 1,24 & 2,84 & 8,95 & 6,45 & 5,94 \\
\hline & & DP & 0,05 & 0,04 & 6,21 & 0,09 & 0,03 & 0,10 & 0,08 & 0,11 & 0,06 & 0,08 & & 0,09 & 0,04 & 0,10 & 0,28 & 0,13 & 0,19 \\
\hline & & Mín & 2,60 & 3,38 & 1,89 & 1,17 & 0,59 & 1,04 & 1,69 & 2,21 & 2,28 & 1,04 & 1,82 & 1,43 & 1,17 & 2,67 & 8,58 & 6,31 & 5,59 \\
\hline & & Máx & 2,73 & 3,51 & 1,95 & 1,43 & 0,65 & 1,30 & 1,95 & 2,54 & 2,41 & 1,30 & 2,15 & 1,63 & 1,30 & 2,99 & 9,36 & 6,63 & 6,18 \\
\hline C. tuiucauna & q & & 2,72 & 3,20 & 1,76 & 1,36 & 0,64 & 1,20 & 1,68 & 2,48 & 2,48 & 1,20 & 1,92 & 1,60 & 1,20 & 2,72 & 8,56 & 6,08 & 5,44 \\
\hline \multirow[t]{8}{*}{ C. vanduzeei } & क & Méd & 2,39 & 2,88 & 1,63 & 1,24 & 0,57 & 1,04 & 1,66 & 2,11 & 2,08 & 0,94 & 1,64 & 1,46 & 1,11 & 2,08 & 6,34 & 4,57 & 4,16 \\
\hline & & DP & 0,06 & 0,03 & 0,05 & 0,05 & 0,03 & 0,05 & 0,04 & 0,05 & - & 0,04 & 0,06 & 0,06 & 0,05 & 0,12 & 0,19 & 0,19 & 0,18 \\
\hline & & Mín & 2,34 & 2,86 & 1,56 & 1,17 & 0,52 & 0,98 & 1,63 & 2,08 & 2,08 & 0,91 & 1,56 & 1,37 & 1,04 & 1,95 & 6,24 & 4,36 & 4,03 \\
\hline & & Máx & 2,47 & 2,93 & 1,69 & 1,30 & 0,59 & & 1,69 & 2,15 & 2,08 & 0,98 & 1,69 & 1,50 & 1,17 & 2,21 & 6,63 & 4,81 & 4,42 \\
\hline & $q$ & Méd & 2,56 & 3,07 & 1,73 & 1,34 & 0,59 & 1,12 & 1,74 & 2,21 & 2,10 & 1,00 & 1,69 & 1,68 & 1,21 & 2,30 & 6,89 & 5,15 & 4,56 \\
\hline & & DP & 0,07 & 0,18 & 0,13 & 0,04 & 0,05 & 0,07 & 0,12 & 0,12 & 0,10 & 0,07 & 0,06 & 0,07 & 0,10 & 0,21 & 0,41 & 0,36 & 0,24 \\
\hline & & Mín & 2,47 & 2,86 & 1,56 & 1,30 & 0,52 & 1,04 & 1,56 & 2,08 & 2,02 & 0,91 & 1,63 & 1,56 & 1,11 & 2,02 & 6,37 & 4,55 & 4,23 \\
\hline & & Máx & 2,67 & 3,25 & 1,89 & 1,37 & 0,65 & 1,24 & 1,82 & 2,34 & 2,21 & 1,11 & 1,76 & 1,76 & 1,30 & 2,60 & 7,41 & 5,53 & 4,88 \\
\hline
\end{tabular}

póstero-laterais pouco projetados (Fig. 10) e com as margens laterais convexas. Taça genital moderadamente escavada. Projeção mediana do bordo dorsal retilínea no ápice; terços laterais do bordo dorsal levemente projetados sobre a taça genital. Abas do bordo ventral levemente dobradas sobre a taça genital; superfícies das abas e da margem lateral externa côncavas, emarginadas e denteadas em toda sua extensão, com um dente apical curvo dirigido ântero-lateralmente (Fig. 10); margens laterais internas sinuosas, formando um "U" aberto mediano quando observadas em vista posterior (Fig. 12). Recorte mediano do bordo ventral amplo (Fig. 11). Depressão do bordo ventral rasa, carena conspícua. Segmento $\mathrm{X}$ pouco mais largo no ápice, com escavação rasa na base; carena sinuosa (Figs. 10, 12). Parâmeros com a base pouco mais longa que o corpo (Fig. 22). Processo basal do parâmero com região proximal ampla, curvo anteriormente, de comprimento subigual ao corpo do parâmero; corpo do parâmero não recurvado lateralmente, ápice subtriangular (Figs. 22-24). Phalloteca com superfície ventral fortemente côncava, abertura póstero-ventral (Fig. 35). Vésica retilínea, com diâmetro igual ao diâmetro do ductus seminis proximalis. Processos da vésica mais longos que esta, levemente curvos em direção ventral e com ápices divergentes (Figs.

\section{4,35).}

Genitália da fêmea. Sinuosidade do bordo posterior do segmento VII suave sobre os ângulos basais dos laterotergitos 8 (Fig. 43). Gonocoxitos 8: superfície levemente convexa, ângulos suturais arredondados, bordos suturais justapostos medianamente, bordos posteriores levemente convexos, ângulos póstero-laterais pouco pronunciados. Gonapófises 8 ultrapassando pouco os gonocoxitos 8 . Laterotergitos 9 com ápices arredondados, margens internas levemente côncavas e divergentes, superfície plana. Bordo posterior dos gonocoxitos 9 levemente côncavo; espinho do bordo posterior das gonapófises 9 desenvolvido, atingindo o terço basal dos gonocoxitos 9, não encoberto pelas gonapófises 8 (Fig. 43).

Material tipo. Holótipo ơ, BRASIL, Paraná: Ponta Grossa, 07.IV.1974, A. R. Panizzi col. (DZUP). Parátipos. ơ,

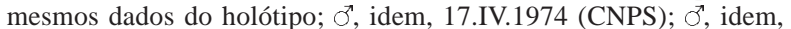
27.VI.1974 (DZRS); O’, idem, 07.IV.1974, B. S. Corrêa col. (AMNH); \&, idem, 10.III.1974, B. S. Corrêa (DZRS); ơ, idem, II.1975, sem dados de coletor (AMNH).

Etimologia. Nome alusivo à coloração vermelhoferrugínea das tíbias.

Planta-hospedeira. Glycine max (L.) Merril (soja).

Distribuição. Brasil (Paraná). 


\section{Chinavia schuhi sp. nov.}

(Figs. 3, 13-15, 25-27, 36, 37, 44, 48)

Diagnose. Coloração geral do corpo verde, com margens da cabeça, pronoto, hemiélitros e conexivo vermelhos; cicatrizes e ângulos basais do escutelo imaculados. Rostro ultrapassando as metacoxas. Diferencia-se de C. aseada (Rolston, 1983) e C. ubica (Rolston, 1983) pela coloração do espiráculo castanhoclara, ângulos umerais mais projetados e bordos posteriores dos gonocoxitos 8 levemente convexos. Diferencia-se de C. nigrodorsata (Breddin, 1901) e $C$. simplicis (Rolston, 1983) pela ausência de calos amarelos junto aos espiráculos.

Medidas. Comprimento médio o/s: 12,76/15,05; largura abdominal: 7,41/8,78. Demais parâmetros morfométricos, Tab. I.

Coloração. Face dorsal verde; margens laterais das jugas, do pronoto, do terço basal do cório, do conexivo e dos urosternitos com uma faixa vermelha (Fig. 3).
Pontuação dorsal verde-escura no pronoto, escutelo e cório; na cabeça, pontuação concolor. Mancha negra entre o olho e a base da antena presente. Antenas predominantemente verdes, com exceção do apical do terceiro e da metade apical do quarto e quinto artículos, manchados de negro. Rostro verde-claro. Cicatrizes do pronoto e ângulos basais do escutelo imaculados. Pernas verdes. Membrana dos hemiélitros transparente, com mancha enfuscada junto ao ângulo basal interno; com os hemiélitros em repouso, a mancha está junto ao ápice do escutelo. Conexivo sem pontuação; ponto negro no ângulo póstero-lateral dos urosternitos inconspícuo. Face ventral verde-clara, com uma faixa mediana longitudinal mais clara que inclui o rostro e as coxas. Pontuações da face ventral concolores; alguns exemplares com pontuações ferrugíneas no tórax. Espiráculos castanhoclaros a castanho-escuros.

Cabeça. Densamente pontuada dorsalmente e pontuação ventral menos densa. Jugas com disco plano, margens retilíneas e convergentes em direção ao ápice,
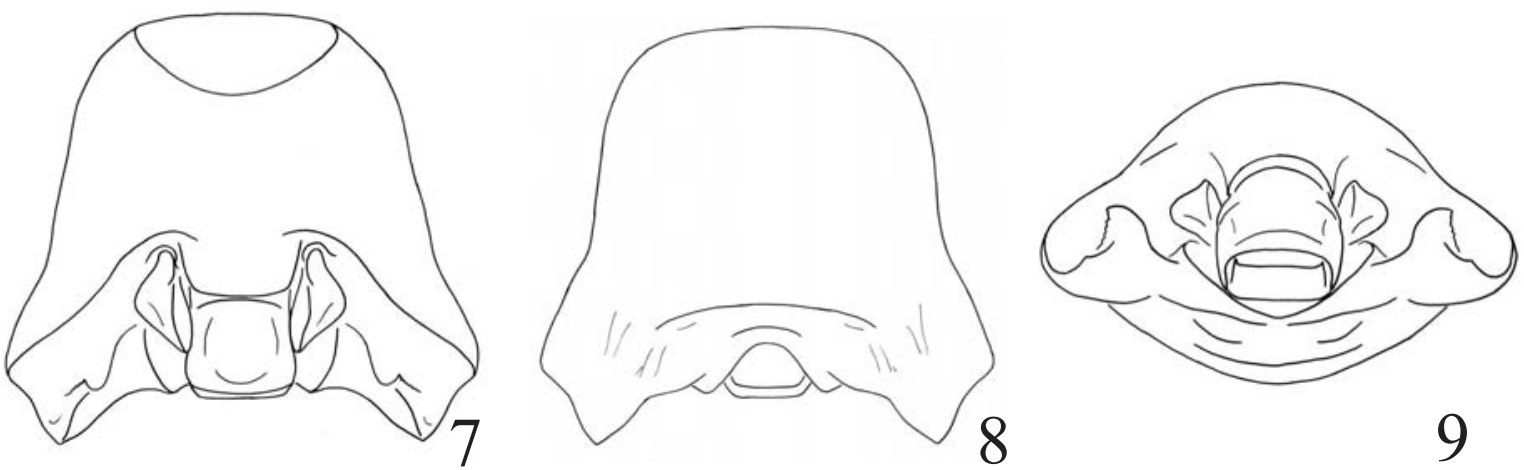

9
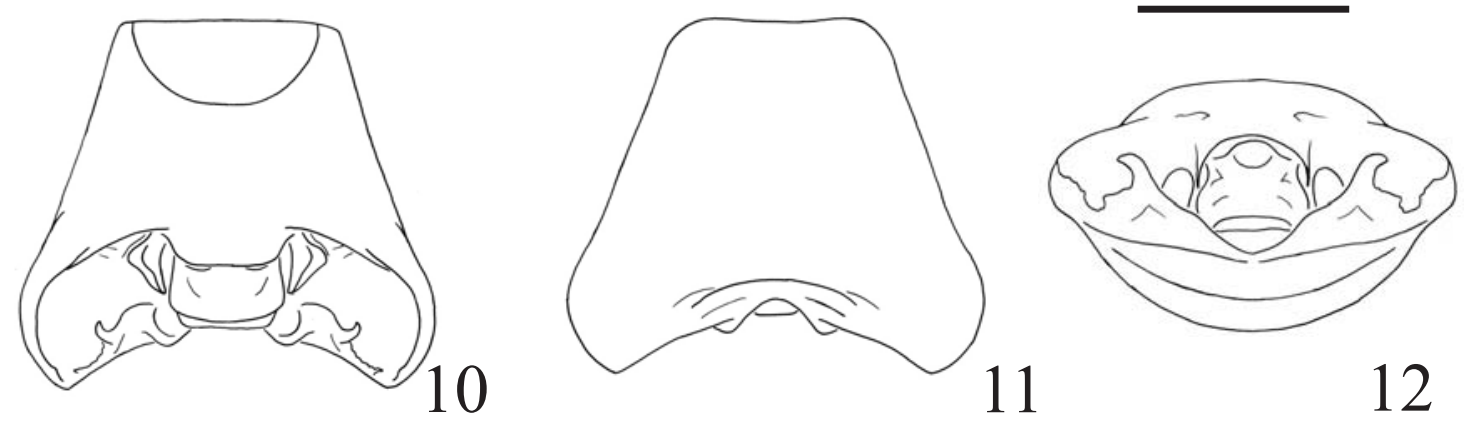

12
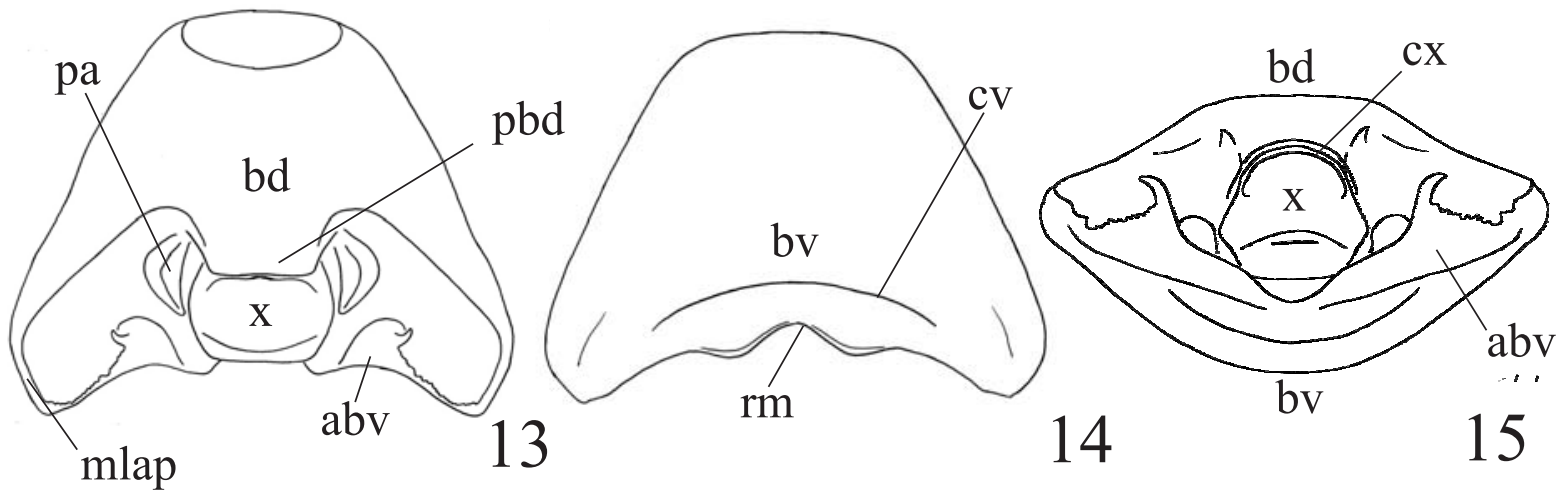

Figs. 7-15. Pigóforo, vistas dorsal, ventral e posterior, respectivamente: 7-9, Chinavia cearensis sp. nov.; 10-12, C. rufitibia sp. nov.; 13-15, C. schuhi sp. nov. (abv, aba do folheto superior do bordo ventral; bd, bordo dorsal; bv, bordo ventral; cv, carena do bordo ventral; cx, carena do segmento X; mlap, margem lateral dos ângulos póstero-laterais; pa, parâmero; pbd, processo do bordo dorsal; $\mathrm{rm}$, recorte mediano do bordo ventral; $\mathrm{x}$, segmento $\mathrm{X}$ ). Escala $=1 \mathrm{~mm}$. 
este de contorno subtriangular. Proporção dos artículos antenais: $\mathrm{I}<\mathrm{II}<\mathrm{III}<\mathrm{IV} \approx \mathrm{V}$ (Tab. I). Rostro com $\mathrm{o}$ comprimento variável, ultrapassando o terceiro urosternito e podendo atingir até o meio do quarto. Proporções dos segmentos do rostro: I $<$ II $>$ III $>$ IV; I $\approx$ IV (Tab. I).

Tórax. Pontuação menos densa que a da cabeça. Margens ântero-laterais do pronoto sub-retilíneas; ângulos umerais levemente projetados. Ângulo costal do cório arredondado, atingindo o bordo posterior do conexivo do VI segmento. Peritrema ostiolar estendendose um pouco além metade da largura da metapleura.

Abdome. Convexo a levemente subtriangular ventralmente. Conexivo com pontuação mais rasa que a da superfície dorsal do corpo; metade da largura do quarto, quinto e sexto segmentos vísiveis em vista dorsal. Espinho do terceiro urosternito inconspícuo, formando um tubérculo rombo que não atinge a margem posterior das metacoxas.

Genitália do macho. Pigóforo com contorno subtriangular; ângulos póstero-laterais pouco projetados (Fig. 13). Taça genital moderadamente escavada. Projeção mediana do bordo dorsal (pbd) retilínea no ápice, terços laterais do bordo dorsal não projetados sobre a taça genital. Margens laterais dos ângulos póstero-laterais (mlap) convexas. Abas do bordo ventral (abv) moderadamente dobradas sobre a taça genital; superfície das abas plana, margem lateral externa defletida, emarginada, côncava e crenulada em toda sua extensão, com um dente apical curvo dirigido ântero-lateralmente (Fig. 13); margem lateral interna côncava, formando um "V" aberto em vista posterior (Fig. 15). Recorte mediano do bordo ventral (rm) amplo. Depressão do bordo ventral rasa, carena mediana (cmv) inconspícua (Figs. 13, 14).
Segmento X levemente arredondado no ápice, com escavação profunda; carena do segmento X (cx) semicircular (Figs. 13, 15). Parâmeros com base (bp) e corpo (cp) subiguais em comprimento e largura (Fig. 25). Processo basal do parâmero (pb) amplo na região proximal, curvo em direção anterior; corpo retilíneo, face interna fortemente côncava; ápice com contorno subtriangular (Figs. 25-27). Phalloteca (ph) com superfície ventral côncava e abertura póstero-ventral (Fig. 37). Vésica (v) curvada ventralmente, afilada no ápice, com diâmetro igual ao do ductus seminis proximalis (dsp); processos (pv) retilíneos, ápices divergentes (Figs. 36, 37).

Genitália da fêmea. Sinuosidade do bordo posterior do segmento VII inconspícua sobre os ângulos basais dos laterotergitos 8 (la8) (Fig. 44). Gonocoxitos 8 (gc8): superfície levemente convexa, ângulos suturais arredondados, bordos suturais não-justapostos e posteriores levemente convexos, ângulos póstero-laterais não-desenvolvidos. Gonapófises 8 (g8) subiguais em comprimento aos gonocoxitos 8. Laterotergitos 9 (la9) com ápices arredondados, margens internas côncavas e levemente divergentes, superfície côncava. Bordo posterior dos gonocoxitos 9 ( $\mathrm{gc} 9$ ) côncavo; espinho do bordo posterior das gonapófises 9 (eg9) bem desenvolvido, ultrapassando o meio dos gonocoxitos 9 , parcialmente encoberto pelas gonopófises 8 (Fig. 44). Espessamento posterior (epiv) pouco esclerotizado; espessamento anterior da íntima vaginal (eaiv) curto, envolvendo apenas o ápice do orificium receptaculi (or). Ductus receptaculi (dr), na região anterior à área vesicular (av), mais de duas vezes o comprimento do ductus receptaculi posterior à área vesicular (Fig. 48). Pars intermedialis (pi) cônica, subigual em comprimento à capsula seminalis (cs), e com o metade do diâmetro desta.

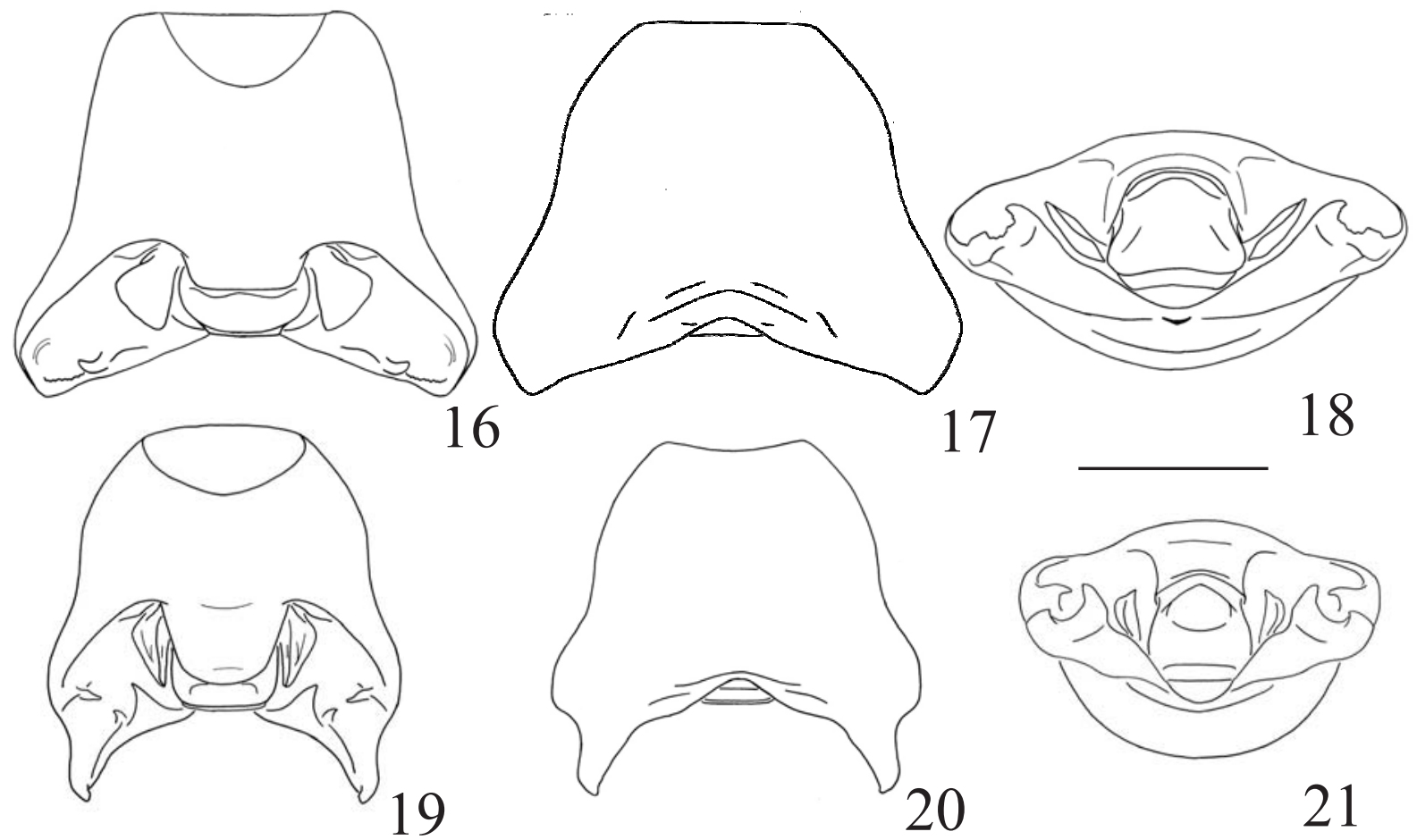

Figs. 16-21. Pigóforo, vistas dorsal, ventral e posterior, respectivamente: 16-18, Chinavia sebastiaoi sp. nov.; 19-21, C. vanduzeei sp. nov. Escala $=1 \mathrm{~mm}$. 
Crista anular anterior (caa) de diâmetro menor que o da crista anular posterior (cap), voltada para a área vesicular; crista anular posterior levemente voltada para a pars intermedialis. Processos da capsula seminalis (pcs) quatro vezes o comprimento da pars intermedialis (Fig. 48).

Material-tipo. Holótipo ơ', PERU, Loreto: médio Rio Ucayali, VIII.1926, F6130, H. Bassler coll., Acc. 33591 (AMNH). Parátipos. \&, COLÔMBIA, Bolívar: Zambrano, Hda. Monterrey, 70 m, 9³7'48'N-7454'44"'W, ., 21.X.1993, F. Fernandez \& G. Ulloa col., Malaise 3, Casa Nueva 7 (IAVH, n. 05097); త゙, mesmos dados do holótipo (DZRS); 9 , BRASIL, Amazonas: Manaus, VII.1935, G. V. Vredenburg col, Brit. Mus. 1935/615 (BMNH); ॐ゙, Br 174, Km 45, 8.IV.1982, E. L. Oliveira (INPA).

Etimologia. Nome em homenagem ao Dr. Randall T. Schuh, curador de Heteroptera do AMNH, cujo trabalho tem sido fundamental no estudo e conhecimento dos heterópteros.

Distribuição. Colômbia (Bolívar), Peru (Loreto) e Brasil (Amazonas).

\section{Chinavia sebastiaoi sp. nov.}

(Figs. 4, 16-18, 28-30, 38, 39, 45, 49)

Diagnose. Coloração geral do corpo verde-clara, com margens da cabeça, do pronoto e do conexivo amareladas, cicatrizes e ângulos basais do escutelo imaculados, membrana dos hemiélitros transparentes. Pontuação da face ventral rasa. Diferencia-se de $C$. abnormis (Berg, 1891) e C. longicorialis (Breddin, 1901) pela sutura da membrana do hemiélitro retilínea; de $C$. esmeralda (Rolston, 1983) pelas jugas fortemente côncavas adiante dos olhos; e de $C$. napea (Stål, 1872) e C. obstinata pelos gonocoxitos 8 planos. Diferencia-se de $C$. difficilis (Stål, 1860) pelos espiráculos de tonalidade clara e de C. geniculata (Dallas, 1851) pelo espinho abdominal ultrapassando as metacoxas e pelas pernas completamente verdes.

Medidas. Comprimento médio ơ/ : 14,44/15,87; largura abdominal 孔/c: 8,65/9,30. Demais parâmetros morfométricos, Tab. I.

Coloração. Face dorsal verde-clara a verde-oliva;
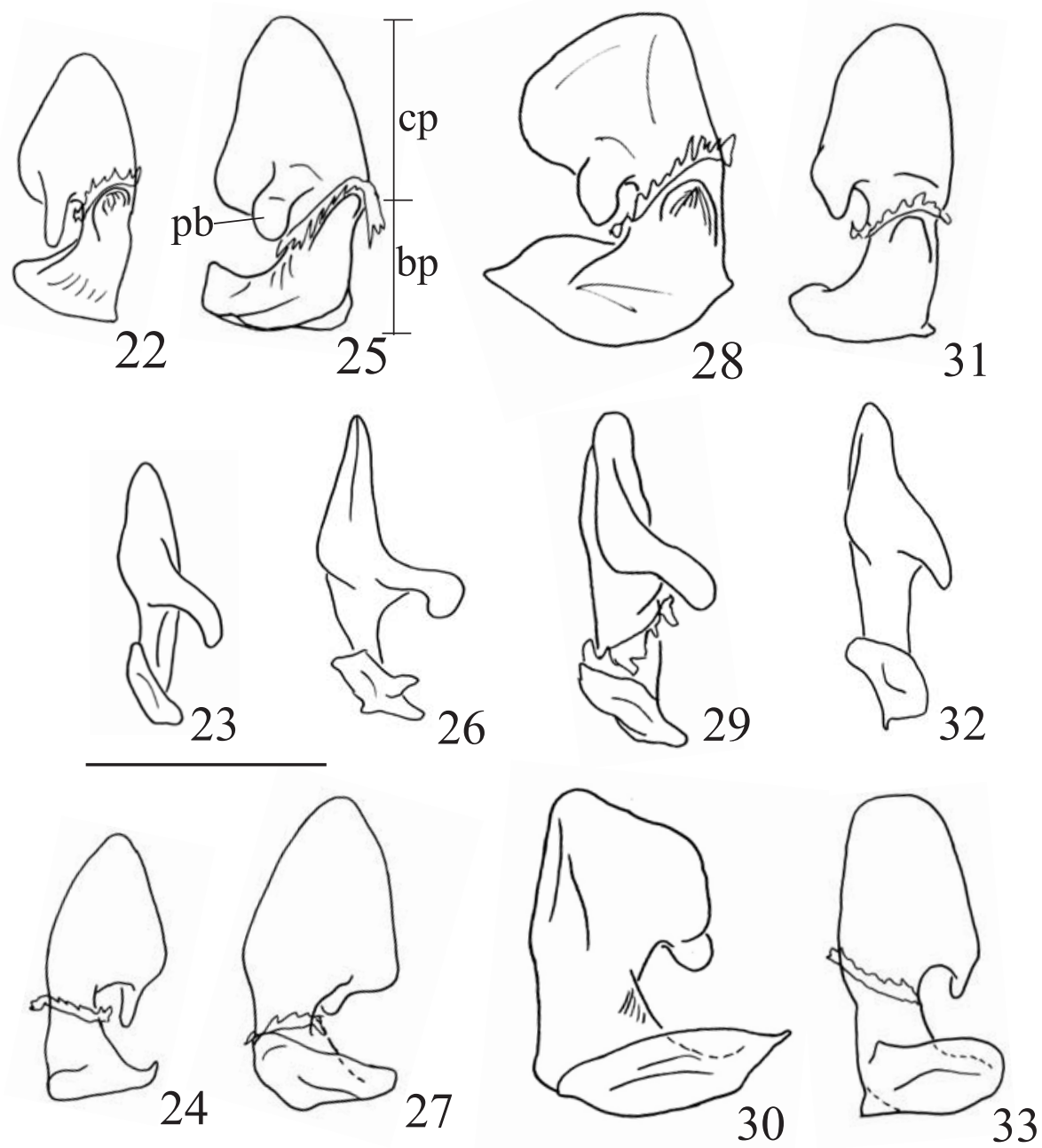

Figs. 22-33. Parâmero direito, vistas lateral interna, dorsal e lateral externa, respectivamente: 22-24, Chinavia rufitibia sp. nov.; 2527, C. schuhi sp. nov.; 28-30, C. sebastiaoi sp. nov.; 31-33, C. vanduzeei sp. nov. (bp, base do parâmero; cp, corpo do parâmero; pb, processo basal do corpo do parâmero). Escala $=0,5 \mathrm{~mm}$. 
margens das jugas e interna dos olhos com estreita faixa amarelo-alaranjada; em alguns espécimes, margens laterais do pronoto, do terço basal do cório e do conexivo amareladas. Pontuação concolor em todo o corpo (Fig. 4). Mancha negra entre o olho e a base da antena presente. Antenas predominantemente verdes, com o quarto apical do terceiro e metade apical do quarto e quinto segmentos negros. Rostro concolor ao corpo. Cicatrizes do pronoto e ângulos basais do escutelo imaculados. Pernas, com exceção das coxas, concolores à superfície dorsal. Membrana dos hemiélitros hialina. Conexivo imaculado. Mancha negra dos ângulos póstero-laterais do urosternito inconspícua. Face ventral verde-clara a ferrugínea, com uma faixa central, que inclui a base da cabeça, esterno e espinho abdominal, mais clara; nos espécimes de coloração verde-oliva, coloração ventral predominantemente ferrugínea. Espiráculos verde-claros a creme-pálidos.

Cabeça. Pontuação pouco mais profunda que a da face dorsal do corpo. Jugas com alguns pontos parcialmente fusionados, formando sulcos transversais rasos. Juga com disco plano; margens fortemente côncavas adiante dos olhos e convexas apicalmente, ápice da cabeça arredondado. Proporção dos artículos antenais: $\mathrm{I}<\mathrm{II}<\mathrm{III}<\mathrm{IV} \approx \mathrm{V}$ (Tab. I). Rostro variando em comprimento, atingindo desde as metacoxas até o meio do terceiro urosternito. Proporções dos segmentos do rostro: $\mathrm{I}<\mathrm{II}>\mathrm{III}<\mathrm{IV}$; I $<\mathrm{IV}$ (Tab. I).

Tórax. Margens ântero-laterais do pronoto levemente convexas a sub-retilíneas; ângulos umerais arredondados. Ângulo costal do cório arredondado, atingindo o bordo posterior do VI segmento do conexivo; sutura da membrana retilínea. Peritrema ostiolar atingindo 3/4 da largura da área evaporatória.

Abdome. Convexo; conexivo com pontuações mais rasas que as da face dorsal do corpo, hemiélitros cobrindo mais da metade da largura do conexivo. Espinho abdominal desenvolvido, comprimido lateralmente, atingindo a margem anterior das metacoxas até o meio das mesocoxas. Pontuações da face ventral rasas, formando sulcos transversais.

Genitália do macho. Pigóforo subquadrangular, ângulos póstero-laterais pouco projetados (Fig. 16). Taça genital moderadamente escavada. Projeção mediana do bordo dorsal retilínea no ápice; terços laterais do bordo dorsal não projetados sobre a taça genital. Margens laterais dos ângulos póstero-laterais convexas. Abas do bordo ventral levemente dobradas sobre a taça genital; superfície das abas côncava, margem lateral externa levemente côncava, emarginada e serrilhada em toda sua extensão, com um dente curvo basal dirigido ântero-lateralmente (Figs. 16, 18); margens laterais internas sub-retilíneas, formando um "U" aberto posteriormente (Fig. 18). Recorte mediano
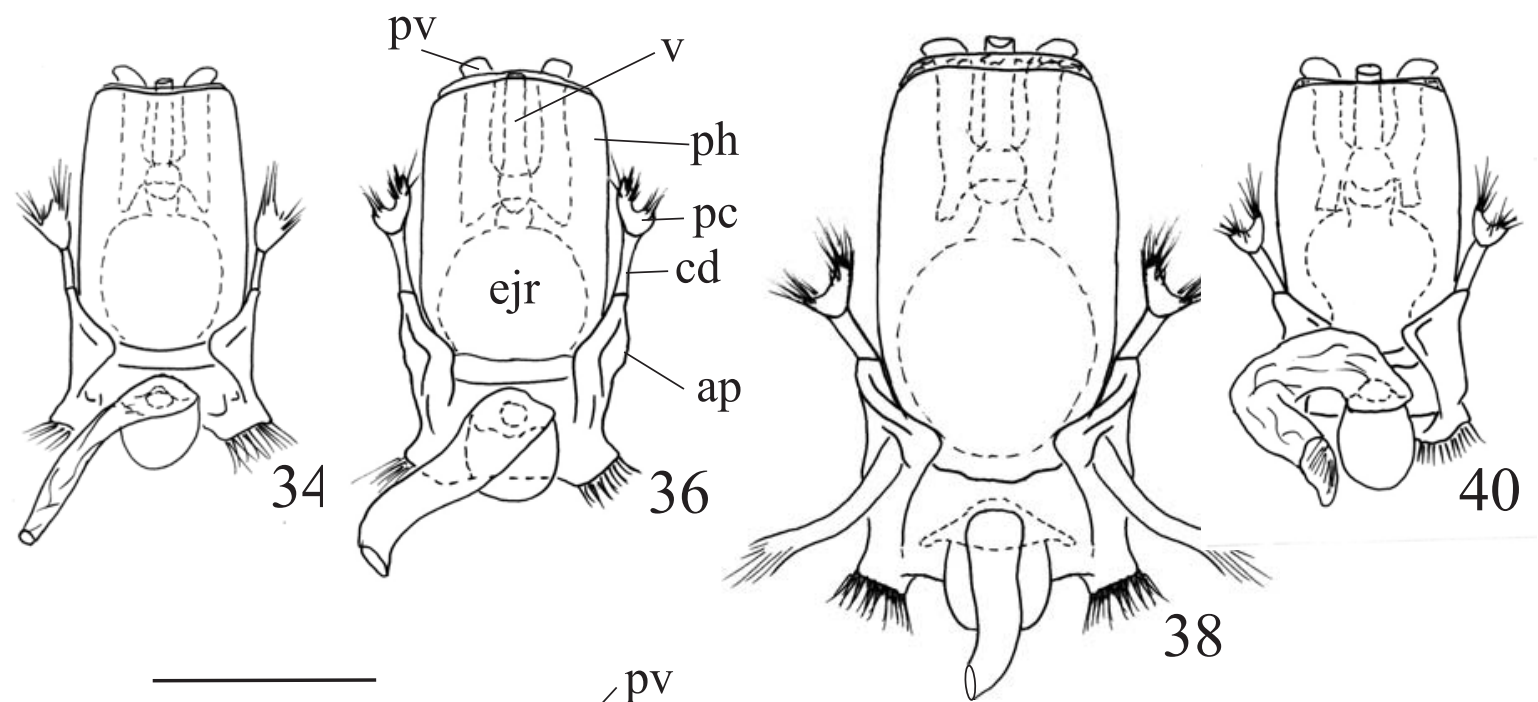

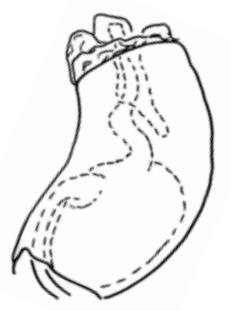

35
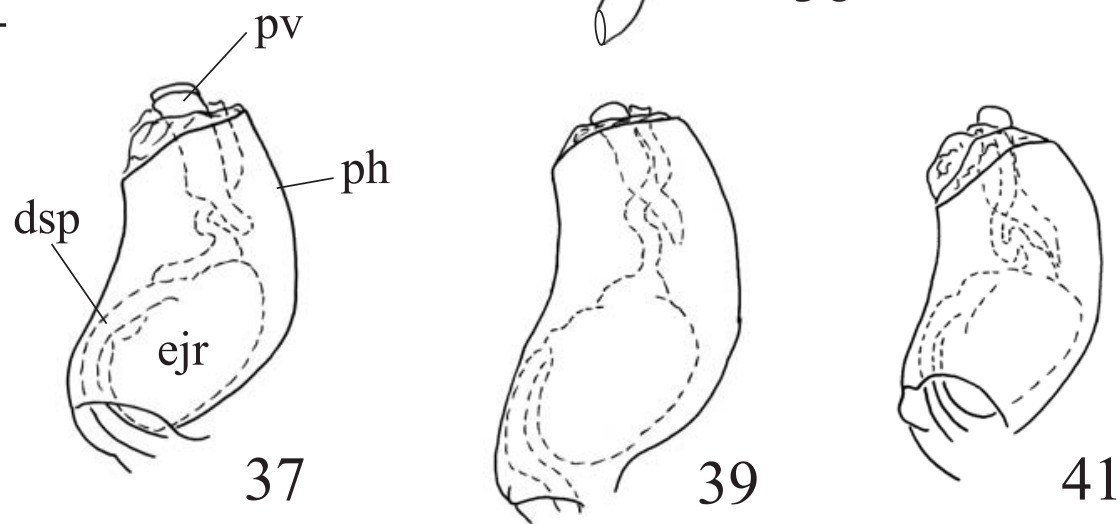

Figs. 34-41. Phallus, vistas dorsal e lateral, respectivamente: 34, 35, Chinavia rufitibia sp. nov.; 36, 37, C. schuhi sp. nov.; 38, 39, C. sebastiaoi sp. nov.; 40, 41, C. vanduzeei sp. nov. (ap, aparelho articular; cd, conectivo dorsal; dsp, ductus seminis proximalis; ejr, ejaculatory reservoir; pc, processus capitati; ph, phallotheca; pv, processos da vésica; v, vésica). Escala = 0,5 mm. 
do bordo ventral amplo. Depressão do bordo ventral moderada, carena conspícua (Fig. 17). Segmento X alargado no ápice, arredondado, com escavação basal rasa; carena do segmento $\mathrm{X}$ sinuosa (Figs. 16, 18). Parâmeros com base mais longa e larga que o corpo; corpo plano, expandido dorsalmente; ápice de contorno truncado (Fig. 28). Processo basal do parâmero levemente curvo no ápice (Figs. 28-30). Phalloteca com superfície ventral côncava e abertura póstero-ventral (Fig. 39). Vésica levemente curvada em direção ventral, com diâmetro pouco maior que o do ductus seminis proximalis. Processos da vésica mais longos que esta, curvos em direção ventral, ápices divergentes (Figs. $38,39)$.

Genitália da fêmea. Sinuosidade do bordo posterior do segmento VII moderada sobre os ângulos basais dos laterotergitos 8 (Fig. 45). Gonocoxitos 8: superfície plana, ângulos suturais subtruncados e emarginados, bordos suturais justapostos medianamente; bordos posteriores levemente sinuosos, ângulos póstero-laterais pouco pronunciados. Gonapófises 8 não ultrapassando os gonocoxitos 8. Laterotergitos 9 com ápices arredondados, margens internas levemente côncavas e divergentes. Bordo posterior dos gonocoxitos 9 levemente côncavo; espinho do bordo posterior das gonapófises 9 desenvolvido, atingindo o terço basal dos gonocoxitos 9, não encoberto pelas gonapófises 8 (Fig. 45). Espessamento posterior da íntima vaginal esclerotizado. Ductus receptaculi na região anterior à área vesicular duas vezes mais longo que na região posterior à mesma área. Pars intermedialis cônica, subigual em comprimento e com metade da largura da capsula seminalis. Crista anular anterior com diâmetro menor que a crista anular posterior, voltada para a área vesicular; crista anular posterior plana. Processos da capsula seminalis três vezes o comprimento da pars intermedialis (Fig. 49).

Etimologia. O nome em aposição é uma homenagem póstuma ao ilustre entomólogo Dr. Sebastião de Oliveira, pesquisador da Fundação Instituto Oswaldo Cruz, pela sua fundamental contribuição à entomologia no Brasil.

Material-tipo. Holótipo đ’, BRASIL, Mato Grosso do

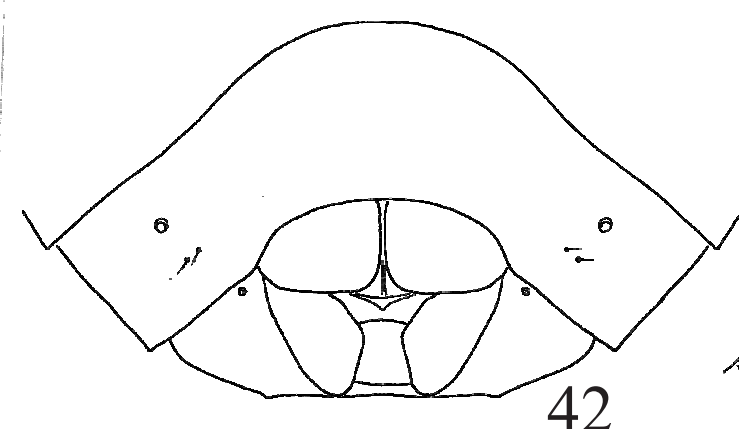

42
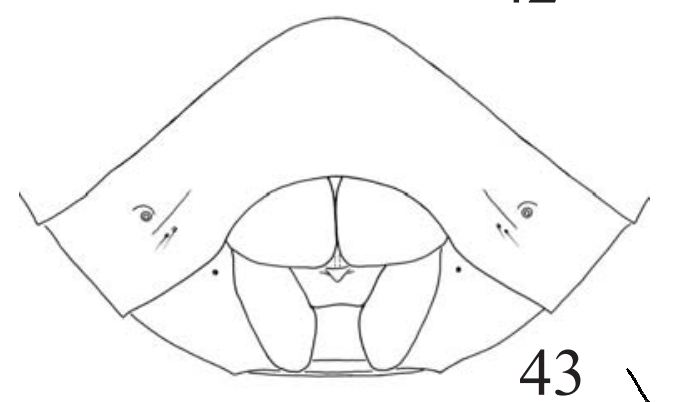

43
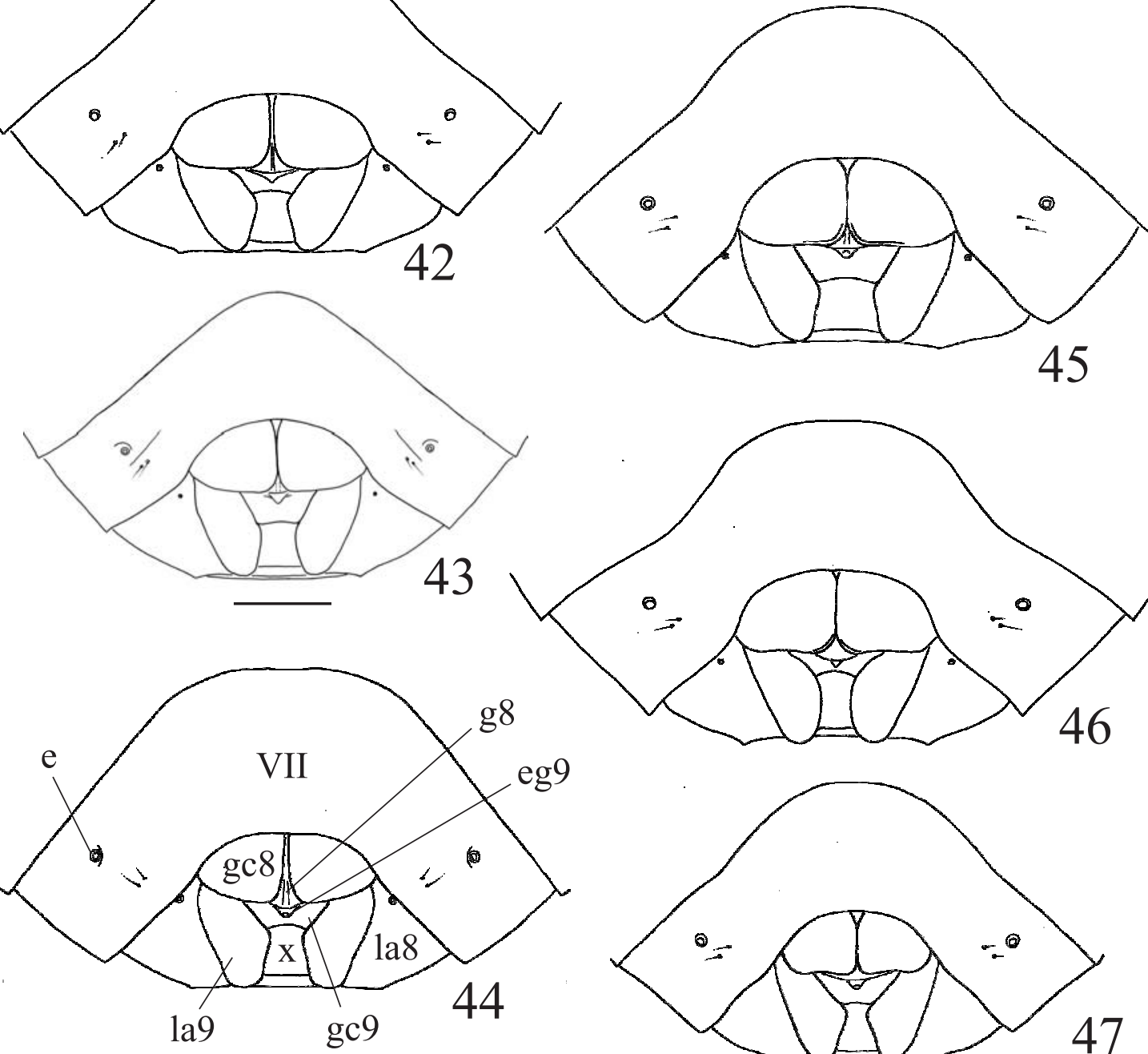

45
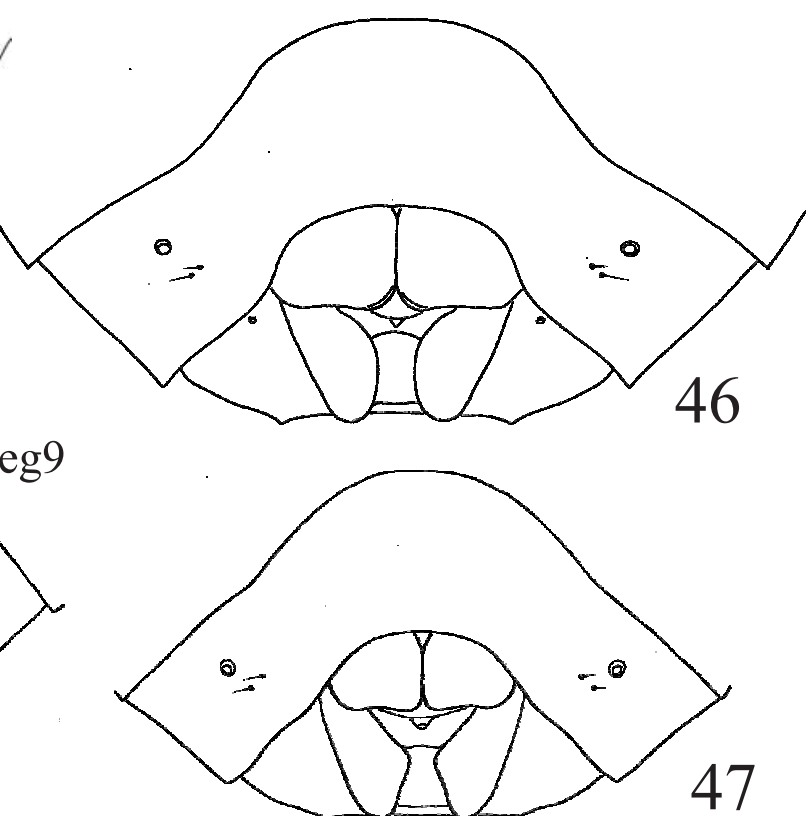

Figs. 42-47. Placas genitais, vista ventral: 42, Chinavia cearensis sp. nov.; 43, C. rufitibia sp. nov.; 44, C. schuhi sp. nov.; 45, C. sebastiaoi sp. nov.; 46, C. tuiucauna sp. nov.; 47, C. vanduzeei sp. nov. (e, espiráculo; eg9, espinho das gonapófises 9; g8, gonapófises 8; gc8, gonocoxitos 8; gc9, gonocoxitos 9; la8, laterotergitos 8; la9, laterotergitos 9; x, segmento X). Escala = 1 mm. 
Sul: Serra da Bodoquena, XI.1941, Com I.O.C. (FIOC, 02761) Parátipos: ơ, BOLÍlVIA, La Paz: Guanay (Coroico), XI.1996

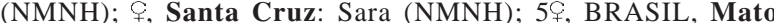
Grosso do Sul: mesmos dados do holótipo (FIOC 02762, 02765 , 02766; DZRS 02769, 02773); f, PARAGUAI: Carumbé, 01.II08.III.1966, R. Golbach (IMLA).

Distribuição. Brasil (Mato Grosso do Sul), Bolívia (La Paz, Santa Cruz) e Paraguai (Carumbé).

\section{Chinavia tuiucauna sp. nov.} (Figs. 5, 46)

Diagnose. Coloração geral do corpo verde-oliva; margens da cabeça e do escutelo com faixa difusa creme a amarelada; cicatrizes, ângulos basais do pronoto e conexivo imaculados; membrana dos hemiélitros transparente; espinho abdominal curto, não atingindo as metacoxas.

Medidas. Comprimento $q: 15,64$; largura abdominal 9,35. Demais parâmetros morfométricos, Tab. I.

Coloração. Face dorsal verde-escura a verde-oliva. Estreita faixa difusa verde-clara a creme na margem junto à base das jugas, contorno dos olhos, margens laterais do pronoto e terço basal dos hemiélitros (Fig. 5). Pontuação concolor com a do corpo. Mancha negra entre o olho e a base da antena ausente. Antenas predominantemente verdes, com anel negro no ápice do primeiro artículo, base e ápice do segundo, metade apical do terceiro e 3/4 apicais do quarto negros; $3 / 4$ do quinto ferrugíneos. Cicatrizes do pronoto e ângulos basais do escutelo imaculados. Pernas verdes. Membrana dos hemiélitros transparente, esverdeada; ângulos internos levemente infuscados. Conexivo mais claro que o restante do corpo, sem manchas negras; ponto negro do ápice dos ângulos póstero-laterais do urosternito inconspícuo. Face ventral verde-clara, esterno e coxas creme. Espiráculos verde-claros, translúcidos.

Cabeça. Comprimento levemente menor que a largura; pontuação pouco mais densa e profunda que a do restante da face dorsal do corpo; alguns pontos parcialmente fusionados no ápice das jugas, formando sulcos transversais rasos. Jugas com superfície do disco irregular; margens côncavas adiante dos olhos, convexas e convergentes posteriormente, ápice da cabeça arredondado. Proporção dos artículos antenais: $\mathrm{I}<\mathrm{II}<\mathrm{III}<\mathrm{IV} \approx \mathrm{V}$ (Tab. I). Rostro com ápice atingindo as metacoxas. Proporção dos segmentos do rostro: $\mathrm{I}<\mathrm{II}>\mathrm{III}>\mathrm{IV} ; \mathrm{I} \approx \mathrm{IV}$ (Tab. I).

Tórax. Margens ântero-laterais do pronoto subretilíneas, levemente emarginadas; pontuações no terço basal parcialmente fusionadas. Ângulos umerais subtruncados. Ângulo costal do cório subtruncado, atingindo o meio do VI segmento do conexivo; sutura da membrana retilínea. Peritrema ostiolar estendendo-se além dos 3/4 da largura da metapleura.

Abdome. Convexo ventralmente. Conexivo sem pontuação. Espinho abdominal curto, comprimido
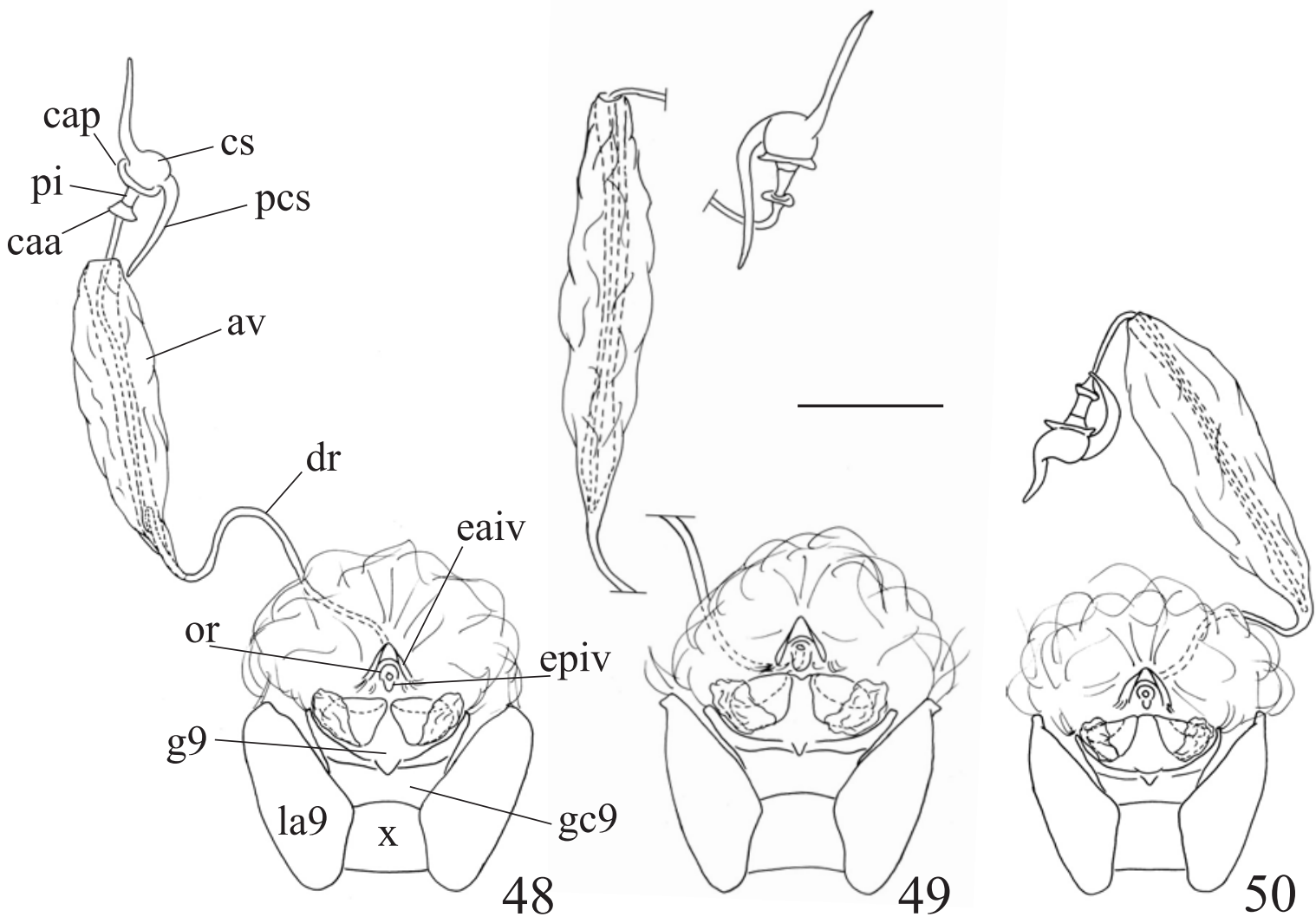

Figs. 48-50. Segmento X, laterotergitos 9, gonocoxitos 9, gonapófises 9 e vias genitais ectodérmicas da fêmea: 48, Chinavia schuhi sp. nov.; 49, C. sebastiaoi sp. nov.; 50, C. vanduzeei sp. nov. (av, área vesicular; caa, crista anular anterior; cap, crista anular posterior; cs, capsula seminalis; dr, ductus receptaculi; eaiv, espessamento anterior da íntima vaginal; epiv, espessamento posterior da íntima vaginal; g9, gonapófises 9; gc9, gonocoxitos 9; la9, laterotergitos 9; or, orificium receptaculi; pcs, processos da capsula seminalis; pi, pars intermedialis; $\mathrm{x}$, segmento $\mathrm{X})$. Escala $=1 \mathrm{~mm}$. 
lateralmente, atingindo o bordo posterior das metacoxas. Genitália da fêmea. Sinuosidade do bordo posterior do segmento VII moderada sobre os ângulos basais dos laterotergitos 8 (Fig. 46). Gonocoxitos 8: superfície plana, ângulos suturais arredondados e emarginados, bordos suturais justapostos e paralelos em toda a extensão; bordos posteriores sinuosos, ângulos póstero-laterais levemente projetados. Gonapófises 8 ultrapassando os gonocoxitos 8. Laterotergitos 9 com ápice arredondado, margens internas levemente convexas e divergentes, superfície côncava. Bordo posterior dos gonocoxitos 9 côncavo; espinho do bordo posterior das gonapófises 9 muito desenvolvido, ultrapassando o meio dos gonocoxitos 9, parcialmente encoberto pelas gonapófises 8 (Fig. 46).

Material-tipo. Holótipo \&, BRASIL, Bahia: Barro Preto, XII.2004, O. M. Marques col. (DZRS).

Etimologia. Nome derivado do tupi-guarani: tuiuca = barro, una = preto, alusivo à localidade-tipo da espécie.

Planta-hospedeira. Theobroma cacao Linnaeus (cacau, Sterculiaceae)

Distribuição. Brasil (Bahia).

Chinavia vanduzeei sp. nov.

(Figs. 6, 19-21, 31-33, 40, 41, 47, 50)

Diagnose. Coloração geral do corpo verde-oliva; ápice da cabeça, margens do corpo, ápice do escutelo e bordo posterior dos hemiélitros de coloração creme. Manchados de negro: antenas, rostro, tíbias e tarsos. Membrana dos hemiélitros enfuscada. O padrão de coloração desta espécie é único dentro do gênero.

Medidas. Comprimento médio s/\$: 11,78/13,33; largura abdominal 6,73/7,49. Demais parâmetros morfométricos, Tab. I.

Coloração. Face dorsal verde-clara a verde-oliva. De coloração creme: metade apical do clípeo e das jugas, uma ampla faixa junto às margens laterais do pronoto, margem lateral e posterior do cório, ápice do escutelo e conexivo (Fig. 6). Manchados de negro: ápice do clípeo, antenas, segmentos II-IV do rostro, tarsos, tíbias e ápice dos fêmures. Nestes, a mancha negra pode se estender em direção proximal em 1+1 faixas laterais. Pontuação, quando presente, castanho-avermelhada. Mancha negra entre o olho e a base da antena ausente. Cicatrizes do pronoto e ângulos basais do escutelo imaculados. Coxas e trocanteres de coloração creme. Membrana dos hemiélitros enfuscada. Conexivo imaculado; ponto negro no ápice dos ângulos póstero-laterais dos urosternitos inconspícuo. Face ventral creme a verde-clara, com pontuações concolores; em alguns exemplares, parte da pontuação ventral do tórax castanho-avermelhada. Espiráculos creme a castanho-claros, translúcidos.

Cabeça. Pontuações mais rasas que as do restante do corpo. Jugas com alguns pontos parcialmente fusionados, formando sulcos transversais rasos. Jugas com superfície do disco irregular; margens fortemente côncavas adiante dos olhos, convexas e convergentes posteriormente, ápice da cabeça arredondado. Clípeo e jugas fracamente decliventes no ápice. Proporção dos artículos antenais: $\mathrm{I}<\mathrm{II}<\mathrm{III}<\mathrm{IV} \approx \mathrm{V}$ (Tab. I). Rostro com comprimento variável, atingindo desde as metacoxas até o meio do terceiro urosternito. Proporção dos segmentos do rostro: $\mathrm{I}<\mathrm{II} \approx \mathrm{III}>\mathrm{IV}$; I $<\mathrm{IV}$ (Tab. I).

Tórax. Margens ântero-laterais do pronoto subretilíneas e emarginadas; ângulos umerais arredondados a subtruncados. Pontuações das margens ântero-laterais do pronoto, ápice do escutelo e hemiélitros pouco mais rasas ou ausentes. Ângulo costal do cório subtruncado, atingindo o meio do VI segmento do conexivo; sutura da membrana sinuosa. Peritrema ostiolar estendendo-se além de 3/4 da largura metapleura.

Abdome. Convexo ventralmente. Conexivo sem pontuações, com os hemiélitros cobrindo mais da metade da sua largura. Espinho abdominal insconspícuo, formando um tubérculo que não atinge as metacoxas.

Genitália do macho. Pigóforo subquadrangular; ângulos póstero-laterais afilados, projetados posteriormente, com ápices convergentes dotados de leve crenulação (Fig. 19). Taça genital pouco escavada, mais rasa nos ângulos póstero-laterais. Projeção mediana do bordo dorsal convexa no ápice, terços laterais do bordo dorsal não projetados sobre a taça genital, com $1+1$ projeções espiniformes no ápice, em aposição ao dente da margem lateral externa da aba do bordo ventral. Margens laterais côncavas junto aos ângulos pósterolaterais. Abas do bordo ventral moderadamente dobradas sobre a taça genital; superfície das abas côncava, margem lateral externa fortemente defletida, retilínea, com um dente curvo dirigido ântero-lateralmente (Figs. 19, 21); margens laterais internas sinuosas, formando um "U" aberto quando vistas posteriormente (Fig. 21). Recorte mediano do bordo ventral amplo (Fig. 20). Depressão do bordo ventral rasa, com carena inconspícua. Segmento X subquadrangular, com escavação moderada na metade basal; carena em semicírculo (Fig. 19, 21). Parâmeros com base e corpo subiguais em comprimento e altura (Fig. 31). Processo da base dos parâmeros curvo em direção anterior; corpo com uma convexidade junto ao ângulo basal, face interna levemente côncava, ápice rombo (Figs. 31- 33). Phalloteca com superfície ventral côncava e abertura póstero-ventral (Fig. 41). Vésica levemente curvada em direção ventral; diâmetro subigual ao do ductus seminis proximalis; processos curvos em direção ventral, ápices divergentes (Figs. 40, 41).

Genitália da fêmea. Sinuosidade do bordo posterior do segmento VII inconspícua sobre os ângulos basais dos laterotergitos 8 (Fig. 47). Gonocoxitos 8: superfície plana, ângulos suturais emarginados, bordos suturais justapostos medianamente, bordos posteriores sinuosos e ângulos póstero-laterais desenvolvidos, fortemente convexos. Gonapófises 8 ultrapassando os gonocoxitos 8. Laterotergitos 9 com ápices arredondados, margens internas divergentes, superfície levemente côncava. Bordo posterior dos gonocoxitos 9 côncavo; espinho do bordo posterior das gonapófises 9 bem desenvolvido, ultrapassando o meio dos gonocoxitos 9, parcialmente encoberto pelas gonapófises 8 (Fig. 47). Porção posterior do espessamento da íntima vaginal pouco esclerotizada. Ductus receptaculi na região anterior à área vesicular menos de uma vez e meia o comprimento do ductus receptaculi posterior à mesma área, ambos mais curtos 
que a área vesicular (Fig. 50). Pars intermedialis levemente cônica, alargada no ápice, pouco maior em comprimento que a capsula seminalis e com metade da largura desta. Crista anular anterior de diâmetro menor que a crista anular posterior, levemente direcionada para a área vesicular; crista anular posterior voltada para pars intermedialis. Processos da capsula seminalis com o dobro do comprimento da pars intermedialis (Fig. 50).

Material tipo. Holótipo ơ, BRASIL, Pará: Rio Xingu Camp, $52^{\circ} 22^{\prime} \mathrm{W}-3^{\circ} 39^{\prime} \mathrm{S}$, cerca de $60 \mathrm{~km}$ sul de Altamira, 8 12.X.1986, P. Spangler \& O. Flint col. (NMNH). Parátipos: $\sigma^{7}$ PERU, Madre de Dios: Rio Tambopata Reserve, 30 air km SW of Puerto Maldonado, 290m, 1-26.XI.1982, E. S. Rosa col. (CAS); \&, BRASIL, Amazonas: Rio Japurá, 23.VIII.1979, L. Pantaleão (INPA); \&, Ayrão, 10.II.1930, S. M. Klages col., J. C. Lutz collection (NMNH); ơ, Rio Solimões (Igarapé Belém), $7-$ 30.IV.1966, Malkin col.; $\uparrow$, Nova Olinda, Rio Purus, V.1922, S M. Klages col., Carng. Mus. Acc. 6962, Nezara femorata Van Duzee, Paratype, Unpublished manuscript name (CAS); đ', Pará Fordlândia, EPA, 02.XI.1970 (DAR); †, Parque Nacional de Uruá, $65 \mathrm{~km}$ oeste de Itaituba, 9-12.X.1977, B. Ratcliffe col. (DAR); o', Itaituba, 16.X.1977, B. Ratcliffe col. (DZRS); \&, Maranhão: Buriticupu, 30.IX.1978, mata de terra firme, isca iluminada, captura noturna (DZRS).

Etimologia. Nome em homenagem a Edward P. Van Duzee, entomólogo norte-americano, pela sua contribuição ao conhecimento dos pentatomídeos.

Distribuição. Peru (Madre de Dios) e Brasil (Amazonas, Pará, Maranhão)

Agradecimentos. Aos curadores das coleções citadas, pelo empréstimo do material de estudo. Ao CNPq, pela concessão de bolsa de doutorado e de produtividade, respectivamente, ao primeiro autor e ao segundo autor. A Luciano Moura (MCNZ), pela ajuda na sugestão do nome de $C$. tuiucauna.

\section{REFERÊNCIAS BIBLIOGRÁFICAS}

Ahmad, I. 1996. A revision of the green stink bug tribe Pentatomini Leach (Hemiptera: Pentatomidae: Pentatominae) from Indo-Pakistan subcontinent with special reference to their cladistics. Proceedings of the Pakistan Congress of Zoology 16:41-86.

DAy, G. M. 1965 (1964). Revision of Acrosternum auctt. nec Fieber from Madagascar. Annals and Magazine of Natural History 7:559-565.

Dupuis, c. 1970. Heteroptera. In: Tuxen, S. L. ed. Taxonomist's glossary of genitalia in insects. Copenhagen, Munksgaard. p.190-209.

Frey-da-Silva, A. \& Grazia, J. 2001. Novas espécies de Acrosternum Fieber, subgênero Chinavia Orian (Heteroptera, Pentatomidae, Pentatomini). Iheringia, Série Zoologia, (90):107-126.

Orian, A. J. E. 1965. A new genus of Pentatomidae from Africa, Madagascar and Mauritius (Hemiptera). Procedings of the Royal Entomological Society of London 34:2529

Panizzi, R. A.; McPherson, J. E.; James, D. G.; Javaherry, M. \& McPherson, R. M. 2000. Stink bugs (Pentatomidae). In: Schaefer, C. \& PANizzi, A. R. eds. Heteroptera of economic importance. Boca Raton, CRC. p.421-474.

Rider, D. A. 2005. Pentatomoidea home page. North Dakota State University. Disponível em:<http:// www.ndsu.nodak.edu/ndsu/rider/Pentatomoidea/>. Acesso em:01.09.2005.

Roche, P. J. L. 1977. Pentatomidae of the granitic islands of Seychelles (Heteroptera). Revue de Zoologie Africaine 91(3):558-572.

Rolston, L. H. 1983. A revision of the genus Acrosternum Fieber, subgenus Chinavia Orian, in the western hemisphere (Hemiptera: Pentatomidae). Journal of the New York Entomological Society 84(1):97-176.

Schwertner, C. F.; Albuquerque, G. S. \& Grazia, J. 2002. Descrição dos estágios imaturos de Acrosternum (Chinavia) ubicum Rolston (Heteroptera: Pentatomidae) e efeitos do alimento no tamanho e coloração das ninfas. Neotropical Entomology 31(4):571-579. 